\title{
GMR
}

\section{Bayesian analyses of genetic parameters for growth traits in Nellore cattle raised on pasture}

\author{
F.B. Lopes ${ }^{1}$, J.L. Ferreira ${ }^{2}$, R.B. Lobo ${ }^{3}$ and G.J.M. Rosa ${ }^{1}$ \\ ${ }^{1}$ Department of Animal Sciences, University of Wisconsin, Madison, WI, USA \\ ${ }^{2}$ Curso de Medicina Veterinária, Universidade Federal do Tocantins, \\ Araguaína, TO, Brasil \\ ${ }^{3}$ Associação Nacional de Criadores e Pesquisadores, Ribeirão Preto, SP, Brasil \\ Corresponding author: F.B. Lopes \\ E-mail: camult@gmail.com
}

Genet. Mol. Res. 16 (3): gmr16039606

Received January 12, 2017

Accepted June 7, 2017

Published July 6, 2017

DOI http://dx.doi.org/10.4238/gmr16039606

Copyright (C) 2017 The Authors. This is an open-access article distributed under the terms of the Creative Commons Attribution ShareAlike (CC BY-SA) 4.0 License.

\begin{abstract}
This study was carried out to investigate (co)variance components and genetic parameters for growth traits in beef cattle using a multi-trait model by Bayesian methods. Genetic and residual (co) variances and parameters were estimated for weights at standard ages of 120 (W120), 210 (W210), 365 (W365), and 450 days (W450), and for pre- and post-weaning daily weight gain (preWWG and postWWG) in Nellore cattle. Data were collected over 16 years (1993-2009), and all animals were raised on pasture in eight farms in the North of Brazil that participate in the National Association of Breeders and Researchers. Analyses were run by the Bayesian approach using Gibbs sampler. Additive direct heritabilities for W120, W210, W365, and W450 and for preWWG and postWWG were $0.28 \pm 0.013,0.32 \pm 0.002,0.31 \pm$ $0.002,0.50 \pm 0.026,0.61 \pm 0.047$, and $0.79 \pm 0.055$, respectively. The estimates of maternal heritability were $0.32 \pm 0.012,0.29 \pm 0.004,0.30$ $\pm 0.005,0.25 \pm 0.015,0.23 \pm 0.017$, and $0.22 \pm 0.016$, respectively, for $\mathrm{W} 120, \mathrm{~W} 210, \mathrm{~W} 365$, and W450 and for preWWG and postWWG. The estimates of genetic direct additive correlation among all traits were positive and ranged from $0.25 \pm 0.03$ (preWWG and postWWG) to
\end{abstract}

Genetics and Molecular Research 16 (3): gmr16039606 
$0.99 \pm 0.00$ (W210 and preWWG). The moderate to high estimates of heritability and genetic correlation for weights and daily weight gains at different ages is suggestive of genetic improvement in these traits by selection at an appropriate age. Maternal genetic effects seemed to be significant across the traits. When the focus is on direct and maternal effects, W210 seems to be a good criterium for the selection of Nellore cattle considering the importance of this breed as a major breed of beef cattle not only in Northern Brazil but all regions covered by tropical pastures. As in this study the genetic correlations among all traits were high, the selection based on weaning weight might be a good choice because at this age there are two important effects (maternal and direct genetic effects). In contrast, W120 should be preferred when the objective is improving the maternal ability of the dams. Furthermore, selection for postWWG can be used if the animals show both heavier weaning weights and high growth rate after weaning because it is possible to shorten the time between weaning and slaughter based on weaning weight, postWWG, and desired weight at the time of slaughter.

Key words: Animal breeding; Genetic parameters; Bayesian estimates; Maternal effects; Zebu

\section{INTRODUCTION}

As is well known, genetic variability plays a major role in successful animal breeding programs, because there is always a need for the best animals to be selected, animals that are nutritionally efficient and productive. However, the livestock system is complex, because the important economic traits are all affected by genetic and environmental factors and their interactions. Thus, once these factors are fitted it is possible to estimate genetic parameters, which are essential for the design of animal breeding, and it is possible to predict the animal breeding values and the genetic gain for those selection criteria that have an economic impact on livestock system.

Traditionally, pedigree-based mixed models (Henderson, 1976) are used to distinguish signals of genetic merit from environmental noise. Extensions of this method include multi-trait models (Buch et al., 2011; Lopes et al., 2013; VanRaden et al., 2014) and random regression models (Karacaören et al., 2006; Mrode and Coffey, 2008; Boligon et al., 2011; Laureano et al., 2014). Methods that assist in the estimation of (co)variance components and also help to increase the accuracy of breeding values are indeed required. Thus, the use of Bayesian approaches might be a good choice.

The estimation of (co)variance components has been widely and well done using restricted maximum likelihood methods (Meyer, 1997; Albuquerque and Meyer, 2005; Malhado et al., 2005; Lopes et al., 2008; Ferreira et al., 2015). However, such methods include the use of approximations, assume normality, provide approximate confidence intervals for genetic parameters, and do not estimate the distribution and variance of the estimators. On the other hand, the Bayesian methods can fix these problems by providing probability intervals accurately for the estimation of genetic parameters, as data can be correctly distributed $a$ posteriori, regardless of their extension (Faria et al., 2007; Malhado et al., 2012). Thus, this

Genetics and Molecular Research 16 (3): gmr16039606 
study was carried out to estimate genetic parameters and (co)variances for growth traits in Nellore cattle raised on pastures in the North of Brazil using Bayesian inference.

\section{MATERIAL AND METHODS}

It was used records of weight at standard ages of 120 (W120), 210 (W210), 365 (W365), and 450 (W450) days and pre-weaning daily weight gain (preWWG) and post-weaning daily weight gain (postWWG) of Nellore cattle, born between 1993 and 2009, raised on pasture in eight farms from Northern Brazil participating in the Brazilian Society of Breeders and Researchers.

Exploratory analysis was run using Statistical Analysis Systems (SAS, 2004) to check the consistency of the data and to evaluate the significance of environmental sources of variation that can affect the traits, such as current farm, season of birth along the years, classified into two groups [born in the dry season (April-September) and born in the rainy season (October-March)], and sex and cow age at calving, as coverable. Records with 3.5 standard deviations above or below of the mean were discarded. Contemporary groups presenting less than fifty animals or sires with less than five offspring were also removed from the final dataset. It was made a quadratic regression of the weights and the daily weights gain by the age of dam at calving to evaluate if this coverable should be used in the genetic analyses. Hence, as shown in Figure 1, the dam age at calving helped to fit all traits except for the postWWG, which there is no biological explanation for its trend. The relationship matrix was composed of 68,507 animals.
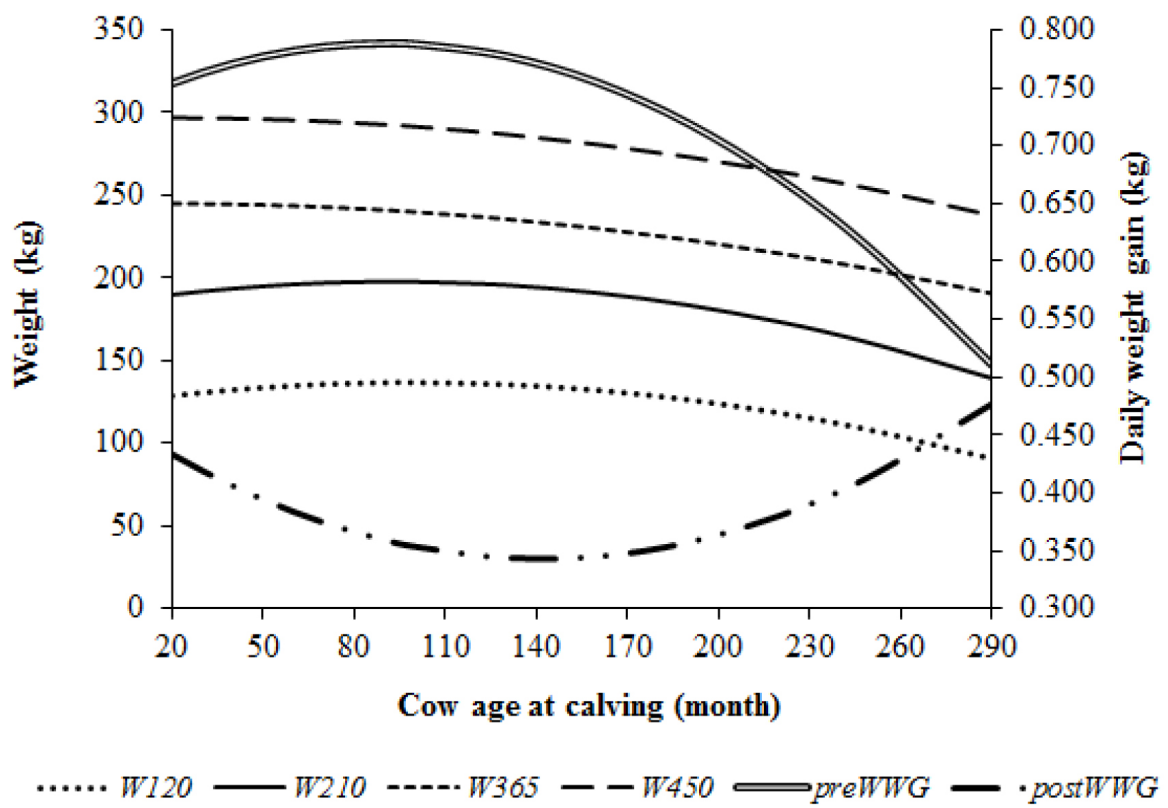

Figure 1. Regression of the weights and the daily weights gain by cow age at calving. W120, weight at 120 days old; W210, weight at 210 days old; W365, weight at 365 days old; W450, weight at 450 days old; preWWG, preweaning daily weight gain; postWWG, post-weaning daily weight gain.

Genetics and Molecular Research 16 (3): gmr16039606 
Genetic analyses were carried out by fitting a model that included the following effects: age of dam as coverable, sex of the animal coded into two levels (male or female), the season of birth over the years, and the effect of the management on the farm. To define the fixed effects included in the contemporary groups (Table 1), the general linear model procedure was used.

\begin{tabular}{|c|c|c|c|c|c|c|}
\hline & \multicolumn{6}{|c|}{ Trait } \\
\hline & preWWG & W120 & W210 & postWWG & W365 & W450 \\
\hline \multicolumn{7}{|l|}{ Data structure } \\
\hline No. contemporary groups & 125 & 153 & 153 & 109 & 170 & 134 \\
\hline No. records & 14,685 & 20,785 & 20,115 & 13,096 & 20,059 & 16,462 \\
\hline No. of sires & 248 & 562 & 389 & 54 & 285 & 117 \\
\hline No. of dams & 9,565 & 13,444 & 12,661 & 6,491 & 12,568 & 9,357 \\
\hline \multicolumn{7}{|l|}{ Summary statistics } \\
\hline Mean $(\mathrm{kg})$ & 0.760 & 132.84 & 192.04 & 0.390 & 243.74 & 286.79 \\
\hline STD $(\mathrm{kg})$ & 0.130 & 19.20 & 27.54 & 0.130 & 36.24 & 43.24 \\
\hline $\mathrm{CV}(\%)$ & 17.43 & 14.45 & 14.34 & 33.08 & 14.87 & 15.08 \\
\hline \multicolumn{7}{|l|}{ Source of variation ${ }^{\mathrm{a}}$} \\
\hline Season of birth & 1.30 & $29,419.84$ & $66,429.51$ & 1.36 & $152,518.85$ & $156,119.13$ \\
\hline Herd & 2.21 & $66,066.56$ & $131,568.29$ & 2.12 & $247,374.28$ & $370,627.64$ \\
\hline Management group & 0.22 & $3,411.68$ & $9,554.69$ & 1.13 & $43,760.15$ & $78,641.17$ \\
\hline Cow age at calving & 0.65 & $32,896.71$ & $29,726.28$ & 0.66 & $2,099.15$ & $12,023.31$ \\
\hline Linear effect & 3.84 & $161,764.58$ & $227,590.97$ & 0.24 & $65,513.49$ & $46,103.53$ \\
\hline Quadratic effect & 1.30 & $29,419.84$ & $66,429.51$ & 1.36 & $152,518.85$ & $156,119.13$ \\
\hline
\end{tabular}

W120, weight at 120 days old; W210, weight at 210 days old; W365, weight at 365 days old; W450, weight at 450 days old; preWWG, pre-weaning daily weight gain; postWWG, post-weaning daily weight gain. ${ }^{\text {a}}$ All source of variation were significant $(\mathrm{P}<0.001)$.

The fixed effects that significantly influenced the growth traits were included in the subsequent analyses. The maternal permanent environmental effect was included on W120, W210, and preWWG because they have more significant influence on them. Moreover, this effect is an environmental source of variation and not a genetic effect; this was not considered for W365, W450, and postWWG. Therefore, the genetic analysis was run by fitting multitrait animal models. In matrix notation, the mixed linear models for W120, W210, preWWG, W365, W450, and postWWG were:

$$
y=X \beta+Z_{1} a+Z_{2} m+Z_{3} m p e+e \text { with } \operatorname{Cov}(a, m)=A \sigma_{a m} \text { (Equation 1) }
$$

where $\boldsymbol{\beta}$ represents the fixed effects [contemporary groups (as cross-classified effect) and cow age at calving (as linear and quadratic effects) as covariates], associated with the observation (records), vector $\boldsymbol{y}$ by the known matrix $\boldsymbol{X}$ and $\boldsymbol{a}, \boldsymbol{m}$ and $\boldsymbol{m e p}$ are the random effect vectors (direct additive, maternal, and permanent environmental effects) associated with records in $\boldsymbol{y}$ by the incidence matrix $\boldsymbol{Z}_{1}, \boldsymbol{Z}_{2}$, and $\boldsymbol{Z}_{3}$, respectively, and $\boldsymbol{e}$ is the residual vector. $\boldsymbol{Z}_{3}$ does not contain entries and columns for W356, W450, and postWWG. Thus, for pre-weaning traits, maternal effects, (m) and (mpe), are present and its covariance was different of zero. Uniform and Gaussian priors were assumed for fixed and random effects, respectively:

Genetics and Molecular Research 16 (3): gmr16039606 


$$
\begin{aligned}
& \beta \propto \text { constant } \\
& a \mid G_{a} \sim M V N\left[0,\left(A \otimes G_{a}\right)\right] \\
& m \mid G_{m} \sim M V N\left[0,\left(A \otimes G_{m}\right)\right] \\
& m e p \mid E_{m p e} \sim M V N\left[0,\left(I_{n} \otimes E_{m p e}\right)\right] \\
& e \mid R \sim M V N\left[0,\left(I_{n} \otimes R\right)\right]
\end{aligned}
$$

where $A, G_{a}, G_{m}, E_{\text {mpe }}, R$, and $I_{n}$ are the relationship matrix, direct genetic, maternal genetic, maternal permanent environmental, residual covariance, and identity, respectively. For variance components, priors were derivate from inverse Wishart distribution.

$$
\begin{aligned}
& G_{a} \mid S_{a}, v_{a} \sim \operatorname{IW}\left(S_{a} v_{a}, v_{a}\right) \\
& G_{m} \mid S_{m}, v_{m} \sim \operatorname{IW}\left(S_{m} v_{m}, v_{m}\right) \\
& E_{m p e} \mid S_{m p e}, v_{m p e} \sim \operatorname{IW}\left(S_{m p e} v_{m p e}, v_{m p e}\right) \\
& R \mid S_{r}, v_{r} \sim I W\left(S_{r} v_{r}, v_{r}\right)
\end{aligned}
$$

where $S_{a}$ and $v_{a}, S_{m}$ and $v_{m}, S_{m p e}$ and $v_{m p e}$, and $S_{r}$ and and $v_{r}$ are a priori values and degrees of freedom for direct genetic, maternal genetic, maternal permanent environmental, and residual covariance, respectively.

The analysis was run using the Gibbsf90 program (Misztal et al., 2015). The marginal posterior distribution for each parameter was obtained by integration of multivariate density functions, considering one long chain with 1,500,000 iterates. The first discard was 500,000, and the thinning interval of the chain was 1000. Serial correlations for the Gibbs sampler were obtained using the GIBANAL software (Van Kaam, 1997). Convergence was checked by visual inspection of the sample trace plots.

Direct genetic $\left(\sigma_{a}^{2}\right)$, maternal genetic $\left(\sigma_{m}^{2}\right)$, covariance between the direct and maternal genetic $\left(\sigma_{a m}\right)$, maternal permanent environmental $\left(\sigma_{p e}^{2}\right)$, and residual variances $\left(\sigma_{e}^{2}\right)$ were estimated by the Gibbs2f90 program (Misztal et al., 2015). The follow (co)variance components and parameters were calculated as in Willham (1972), phenotypic variance for pre-weaning weight $\left(\sigma_{p}^{2}=\sigma_{a}^{2}+\sigma_{m}^{2}+\sigma_{a m}+\sigma_{p e}^{2}+\sigma_{e}^{2}\right)$, postweaning weight $\left(\sigma_{p}^{2}=\sigma_{a}^{2}+\sigma_{m}^{2}+\sigma_{a m}+\sigma_{e}^{2}\right)$, direct heritability $\left(h_{a}^{2}=\sigma_{a}^{2} / \sigma_{p}^{2}\right)$, maternal heritability $\left(h_{m}^{2}=\sigma_{m}^{2} / \sigma_{p}^{2}\right)$, genetic correlation between the direct and maternal effect $\left(r_{a m}\right)$, and maternal permanent environmental variance as a proportion of the phenotypic variance $\left(c^{2}=\sigma_{p e}^{2} / \sigma_{p}^{2}\right)$.

\section{RESULTS}

Convergence of the chain was observed running the Markov Chain diagnosis tests

Genetics and Molecular Research 16 (3): gmr16039606 
with 1,500,000 iterates. The posterior marginal distributions of the (co)variance component were accurately estimated, tending to a normal distribution. The symmetrical distributions of measures of central tendency indicated accurate analysis (Cassela and George, 1992; Silva et al., 2005). In general, the samples obtained for the genetic correlations showed no wide dispersion, i.e., the oscillations remained stable, indicating that the burn-in period considered in the analysis was reliable and allowed convergence of the chain (Gelfand and Smith, 1990). The mean and its standard deviation (SD) in $\mathrm{kg}$ for preWWG, W120, W210, postWWG, W365, and W450 were $0.760 \pm 0.130,132.84 \pm 19.20,192.04 \pm 27.54,0.390 \pm 0.130,243.74$ \pm 36.24 , and $286.79 \pm 43.24$, respectively.

Posterior means of the genetic and residual correlations and (co)variances among growth traits are shown in Tables 2 and 3, respectively, and the descriptive statistics of the posterior distribution for genetic and environmental parameters for weight at standard ages and pre- and post-weaning daily weight gains are shown in Table 4 . The estimates of genetic direct additive correlation among all traits were positives and ranged from $0.25 \pm 0.03$ (preWWG and postWWG) to $0.99 \pm 0.00$ (W210 and preWWG). The correlations of maternal genetic and direct additive genetic effects were found to be high and positive (Table 2) except for post-weaning daily weight gain, where we found moderate to high estimates, but negatives.

\begin{tabular}{|c|c|c|c|c|c|c|c|c|c|c|c|c|c|}
\hline & & \multicolumn{6}{|c|}{ Direct } & \multicolumn{6}{|c|}{ Maternal } \\
\hline & & W120 & W210 & preWWG & W365 & W450 & \begin{tabular}{|l|} 
postWWG \\
\end{tabular} & W120 & W210 & preWWG & W365 & W450 & postWWG \\
\hline \multirow[t]{6}{*}{ Direct } & W120 & 231.950 & 389.345 & 1.779 & 454.674 & 545.224 & 0.643 & 217.924 & 370.380 & 1.750 & \begin{tabular}{|l|}
319.356 \\
\end{tabular} & 315.747 & -0.297 \\
\hline & W210 & 0.95 & 721.801 & 3.312 & 801.738 & 954.007 & 0.954 & 425.392 & 689.062 & 3.254 & \begin{tabular}{|l|l|}
619.403 \\
\end{tabular} & \begin{tabular}{|l|}
621.379 \\
\end{tabular} & -0.428 \\
\hline & preWWG & 0.95 & 0.99 & 0.015 & 3.618 & 4.288 & 0.004 & 1.964 & 3.179 & 0.015 & 2.887 & 2.913 & -0.002 \\
\hline & W365 & 0.82 & 0.82 & 0.80 & 1334.056 & 1660.076 & 3.570 & 444.506 & 749.963 & 3.558 & \begin{tabular}{|l|l|}
461.049 \\
\end{tabular} & \begin{tabular}{|l|}
382.880 \\
\end{tabular} & -1.673 \\
\hline & W450 & 0.77 & 0.77 & 0.75 & 0.98 & 2149.317 & 4.976 & 524.234 & 888.212 & 4.226 & 511.988 & \begin{tabular}{|l|}
362.727 \\
\end{tabular} & -2.339 \\
\hline & postWWG & 0.33 & 0.27 & 0.25 & 0.75 & 0.83 & 0.017 & 0.402 & 0.816 & 0.004 & -0.463 & \begin{tabular}{|l|}
-1.095 \\
\end{tabular} & -0.008 \\
\hline \multirow[t]{6}{*}{ Maternal } & W120 & 0.89 & 0.98 & 0.99 & 0.76 & 0.70 & 0.19 & 259.826 & 408.674 & 1.925 & \begin{tabular}{|l|}
379.704 \\
\end{tabular} & \begin{tabular}{|l|}
384.390 \\
\end{tabular} & -0.195 \\
\hline & W210 & 0.95 & 0.99 & 0.99 & 0.80 & 0.74 & 0.24 & 0.99 & \begin{tabular}{|l|l|}
661.891 \\
\end{tabular} & 3.117 & \begin{tabular}{|l|}
602.394 \\
\end{tabular} & \begin{tabular}{|l|}
608.397 \\
\end{tabular} & -0.359 \\
\hline & preWWG & 0.95 & 0.99 & 0.99 & 0.80 & 0.75 & 0.25 & 0.98 & 0.99 & 0.015 & 2.828 & 2.848 & -0.002 \\
\hline & W365 & 0.81 & 0.89 & 0.90 & 0.48 & 0.42 & -0.14 & 0.91 & 0.90 & 0.90 & 677.495 & \begin{tabular}{|l|}
729.092 \\
\end{tabular} & 0.387 \\
\hline & W450 & 0.72 & 0.81 & 0.82 & 0.37 & 0.27 & -0.29 & 0.83 & 0.82 & 0.82 & 0.98 & \begin{tabular}{|l|}
824.203 \\
\end{tabular} & 0.739 \\
\hline & postWWG & -0.29 & -0.23 & -0.21 & -0.67 & -0.74 & -0.90 & -0.18 & -0.21 & -0.22 & 0.22 & 0.38 & 0.005 \\
\hline
\end{tabular}

W120, weight at 120 days old; W210, weight at 210 days old; W365, weight at 365 days old; W450, weight at 450 days old; preWWG, pre-weaning daily weight gain; postWWG, post-weaning daily weight gain.

Table 3. Residual covariances (above the diagonal), correlation (below the diagonal) and variances (in bold on the diagonal) for growth traits in Nellore cattle from the multi-trait analysis.

\begin{tabular}{l|c|c|c|c|c|c}
\hline & W120 & W210 & preWWG & W365 & W450 & postWWG \\
\hline W120 & $\mathbf{1 0 6 . 8 4 6}$ & 104.858 & 0.502 & 90.341 & 94.546 & -0.045 \\
\hline W210 & 0.75 & $\mathbf{1 8 1 . 8 3 5}$ & 0.880 & 163.820 & 166.645 & -0.067 \\
\hline preWWG & 0.74 & 1.00 & $\mathbf{0 . 0 0 4}$ & 0.812 & 0.834 & -0.0002 \\
\hline W365 & 0.59 & 0.82 & 0.84 & $\mathbf{2 1 8 . 9 1 9}$ & 161.101 & -0.014 \\
\hline W450 & 0.65 & 0.88 & 0.90 & 0.77 & $\mathbf{1 9 9 . 2 2 3}$ & 0.132 \\
\hline postWWG & -0.15 & -0.17 & -0.11 & -0.03 & 0.32 & $\mathbf{0 . 0 0 1}$ \\
\hline
\end{tabular}

W120, weight at 120 days old; W210, weight at 210 days old; W365, weight at 365 days old; W450, weight at 450 days old; preWWG, pre-weaning daily weight gain; postWWG, post-weaning daily weight gain.

Maternal genetic correlation $\left(\mathrm{r}_{\mathrm{m}}\right.$ ) estimates between all weights and pre-weaning daily gain were high and positive ranging from 0.82 (W210-W450 and preWWG-W450) to 0.99 (W120-W210 and W210-preWWG). On the other hand, maternal genetic correlations were low and negative between postWWG and W120 (-0.18), postWWG and W210 (-0.21) and postWWG and preWWG (0.22). All other estimates were positive (Table 2).

Genetics and Molecular Research 16 (3): gmr16039606 
Table 4. Descriptive statistics of the posterior distribution for genetic and environmental parameters for weight at standard ages and weight daily gains.

\begin{tabular}{l|c|c|c|c|c}
\hline Parameter & Mean & SD & \multicolumn{2}{|c|}{ HPD (95\%) } & Time-series SE $^{1}$ \\
\hline$h_{a(W 120)}^{2}$ & 0.2833 & 0.0134 & 0.250 & 0.3144 & 0.0002 \\
\hline$h_{a(W 210)}^{2}$ & 0.3198 & 0.0022 & 0.3201 & 0.3185 & 0.0000 \\
\hline$h_{a(\text { preWWG })}^{2}$ & 0.3097 & 0.0023 & 0.3086 & 0.3088 & 0.0000 \\
\hline$h_{a(\text { W } 365)}^{2}$ & 0.4970 & 0.0257 & 0.4343 & 0.5417 & 0.0005 \\
\hline$h_{a(W 450)}^{2}$ & 0.6100 & 0.0467 & 0.5121 & 0.6728 & 0.0009 \\
\hline$h_{a(\text { postWWG })}^{2}$ & 0.7910 & 0.0552 & 0.6852 & 0.8744 & 0.0010 \\
\hline$h_{m(W 120)}^{2}$ & 0.3177 & 0.0116 & 0.2946 & 0.3385 & 0.0002 \\
\hline$h_{m(W 210)}^{2}$ & 0.2933 & 0.0044 & 0.2871 & 0.2973 & 0.0001 \\
\hline$h_{m(\text { prewWG })}^{2}$ & 0.2981 & 0.0046 & 0.2932 & 0.3018 & 0.0001 \\
\hline$h_{m(W 365)}^{2}$ & 0.2508 & 0.0145 & 0.2193 & 0.2947 & 0.0003 \\
\hline$h_{m(W 450)}^{2}$ & 0.2320 & 0.0166 & 0.2044 & 0.2846 & 0.0003 \\
\hline$h_{m(\text { postWWG }}^{2}$ & 0.2175 & 0.0162 & 0.1678 & 0.2533 & 0.0003 \\
\hline$c_{(W 120)}^{2}$ & 0.0020 & 0.0004 & 0.0012 & 0.0034 & 0.0000 \\
\hline$c_{(W 210)}^{2}$ & 0.0010 & 0.0002 & 0.0006 & 0.0016 & 0.0000 \\
\hline$c_{(\text {preWWG }}^{2}$ & 0.0017 & 0.0003 & 0.0010 & 0.0028 & 0.0000 \\
\hline
\end{tabular}

${ }^{1}$ Time-series SE is the time-series standard error of the component; SD: standard deviation; HPD: high posterior density interval; $h_{a}^{2}$ is the direct heritability; $h_{m}^{2}$ is the maternal heritability; $c^{2}$ is the maternal permanent environmental variance as a proportion of the phenotypic variance.

Additive direct heritability $\left(h_{a}^{2}\right)$ for weight at 120,210,365, and 450 days of age, and for pre- and post-weaning daily weight gain were $0.28 \pm 0.013,0.32 \pm 0.002,0.31 \pm$ $0.002,0.50 \pm 0.026,0.61 \pm 0.047$, and $0.79 \pm 0.055$, respectively. The estimate of maternal heritability $\left(h_{m}^{2}\right)$ were $0.32 \pm 0.012,0.29 \pm 0.004,0.30 \pm 0.005,0.25 \pm 0.015,0.23 \pm 0.017$, and $0.22 \pm 0.016$, respectively, for weight at 120,210,365, and 450 days of age, and for preand post-weaning daily weight gain. Moderate and high estimates remained fairly similar to pre-weaning traits and within post-weaning traits, respectively. The estimates of maternal permanent environmental $\left(\mathrm{c}^{2}\right)$ for weight at $120,210,365$, and 450 days of age, and for preand post-weaning daily weight gain were $0.002 \pm 0.0004,0.001 \pm 0.0002$, and $0.002 \pm 0.0003$, respectively (Table 3 ).

\section{DISCUSSION}

Moderate estimates of additive variance were observed for W120, W210, and preWWG. An average estimate of direct heritability suggests further scope genetic improvement in weaning weight through mass selection (Table 3). The estimate of maternal genetic effects was again moderate and explained the importance of the maternal genetics in the expression of the phenotype of Nellore cattle for growth traits. Estimate of permanent environmental maternal effect $\left(\mathrm{c}^{2}\right)$ was considerably very low $(0.2 \%$ for $\mathrm{W} 120,0.1 \%$ for $\mathrm{W} 210$, and $0.2 \%$ for preWWG); this indicates that maternal permanent environment although has a role to play for weaning growth traits, in this study its importance declined after that. Although permanent

Genetics and Molecular Research 16 (3): gmr16039606 
maternal environment effect was very low, it may still have some influence on the expression of individual's phenotype as well as can mask effects on pre-weaning such as care and kin or contemporary competition. Thus, we decide to keep them in the analyses of weaning traits.

The genetic correlations between direct additive genetic and maternal additive genetic effects were positive. Therefore, selection for direct additive genetic effects would improve the maternal ability, making it easy to conduct joint selection for pre-weaning traits. Oppositely, postWWG has shown antagonism with other traits and researchers have cited different reasons for this negative estimate. Robinson (1996) reported that this occur due to failure to include some important fixed effects in the model and the inclusion of sire $\mathrm{x}$ year interaction in the model could also lead to a reduction in the negative correlation estimate between the animal effects. However, this could also indicate greater variation between sires and dams, due to either a greater genetic variance or confounding environmental effects (Vergara et al., 2009).

The negative values of correlations may also indicate antagonism between the effects of genes related to growth and the maternal ability and often considered to be a statistical matter rather than a biological issue in animal breeding (Meyer, 1997; Eler et al., 2000). Antagonism between the effects of an individual's genes for growth and those of its dam for a maternal contribution may also be due to natural selection for an intermediate optimum (Tosh and Kemp, 1994). As reported by Heydarpour et al. (2008) and Ferreira et al. (2011), the number of offspring per dam may have increased the dependence between maternal parameters, although other factors such as the number of dams with records also interfere with these estimates.

The direct heritability estimate for post-weaning weights and daily gains were moderate to high, indicating the further scope of genetic improvement through selection in these traits. Estimates of direct heritability as obtained previously for post-weaning live weight by Lopes et al. (2013) for Polled Nellore cattle were similar to the current estimates. Additive direct heritability estimates for postWWG was higher than the earlier estimate. The estimate of the genetic correlation between direct genetic additive and maternal additive effects was from moderate to high and positive except for postWWG that reflected an antagonistic relationship with other traits. This antagonistic effect is sometimes hard to explain, and probably the reason cited before are verisimilar and sufficient to clarify ours results.

The estimates of genetic correlations among all traits were from moderate to high and positive, indicating a strong genetic association between growth traits. High and positive genetic correlation as obtained in the present study was earlier reported by Lopes et al. (2013). Similar high and positive estimates were also reported by Araujo Neto et al. (2011) and Yokoo et al. (2007) in Nellore cattle.

Low estimates of genetic correlation of pre-weaning traits and postWWG indicate that selecting for accelerated growth will not have many benefits on post-weaning daily gains. Genetic correlations of between pre- and post-weaning weights were moderate to high and positive, suggesting that many of the genetic factors that influence body weight at weaning to adult age were the same. It also indicated that selecting animals at weaning will have a positive association with the weight at 15 months. The estimates of maternal genetic correlation between different traits were usually in line with the estimates of genetic correlation; this indicated a strong positive maternal genetic association of different growth traits except on maternal effect for postWWG.

By high genetic correlation of W120 with other traits, it can be said that animals with above average W210 would tend to be above average in genetic merit for W365 and also to W450. However, selecting animals at weaning has a drawback of persisting maternal effect at

Genetics and Molecular Research 16 (3): gmr16039606 
that stage. Therefore, in spite of having a positive genetic association of W120 trait with other traits, such selection criteria cannot be suggested as a criterion for great slaughter weight. Thus, weight at 120 days of age should be preferred when the objective is improving the maternal ability of future dams. On the other hand, reduction of the age of selection from 450 to 365 days would be beneficial for Nellore cattle, looking into the strong genetic correlation between weaning and post-weaning traits.

\section{CONCLUSION}

The moderate to high estimates of heritability and genetic correlation for weights and daily weight gains at different ages are suggestive of genetic improvement in these traits by selection at an appropriate age. Maternal genetic effects seemed to be significant across the traits. When the focus is on direct and maternal effects, W210 seems to be a good criterium for the selection of Nellore cattle considering the importance of this breed as a major breed of beef cattle not only in Northern Brazil but all regions covered by tropical pastures. As in this study the genetic correlations among all traits were high, the selection based on weaning weight might be a good choice because at this age there are two important effects (maternal and direct genetic effects). In contrast, weight at 120 days of age should be preferred when the objective is improving the maternal ability of the dams. Furthermore, selection for post-weaning weight gain can be used if the animals show both heavier weaning weights and high growth rate after weaning, because it is possible to shorten the time between weaning and slaughter based on weaning weight, post-weaning weight gain, and desired weight at the time of slaughter.

\section{Conflicts of interest}

The authors declare no conflict interest.

\section{ACKNOWLEDGMENTS}

The authors are indebted to the ANCP (Brazilian Society of Breeders and Researchers) for providing dataset and genealogical data. The authors also thank the University of WisconsinMadison and FAPEG (Research Support Foundation of the State of Goiás) for providing postdoctoral financial support for F.B. Lopes.

\section{REFERENCES}

Albuquerque LG and Meyer K (2005). Estimates of covariance functions for growth of Nelore cattle applying a parametric correlation structure to model within-animal correlations. Livest. Prod. Sci. 93: 213-222. https://doi.org/10.1016/j. livprodsci.2004.10.006

Araujo Neto FR, Lôbo RB, Mota MD and Oliveira HN (2011). Genetic parameter estimates and response to selection for weight and testicular traits in Nelore cattle. Genet. Mol. Res. 10: 3127-3140. https://doi.org/10.4238/2011.December.19.1

Boligon AA, Baldi F and Albuquerque LG (2011). Estimates of genetic parameters for scrotal circumference using random regression models in Nelore cattle. Livest. Sci. 137: 205-209. https://doi.org/10.1016/j.livsci.2010.11.007

Buch LH, Sørensen MK, Lassen J, Berg P, et al. (2011). Udder health and female fertility traits are favourably correlated and support each other in multi-trait evaluations. J. Anim. Breed. Genet. 128: 174-182. https://doi.org/10.1111/j.1439$\underline{0388.2010 .00904 . x}$

Cassela G and George EI (1992). Explaining the Gibbs Sampler. Am. Stat. 46: 167-174.

Eler JP, Ferraz JBS, Golden BL and Pereira E (2000). Influência da interação touror e banho na estimação da correlação

Genetics and Molecular Research 16 (3): gmr16039606 
entre efeitos genéticos direto e materno em bovinos da raça Nelore. Rev. Bras. Zootec. 29: 1642-1648. https://doi. org/10.1590/S1516-35982000000600007

Faria CU, Ulhôa Magnabosco C, de los Reyes A, Lôbo RB, et al. (2007). Bayesian inference on field data for genetic parameters for some reproductive and related traits of Nellore cattle (Bos indicus). Genet. Mol. Biol. 30: 343-348. https://doi.org/10.1590/S1415-47572007000300008

Ferreira JL, de los Reyes AB, Carvalheiro R and Lôbo RB (2011). Efeitos da inclusão ou não da covarância genética diretamaternal no modelo e dos valores reais das (co)variancias sobre suas estimativas para peso à desmama em bovinos de corte. Cienc. Anim. Bras. 12: 435-442. https://doi.org/10.5216/cab.v12i3.5503

Ferreira JL, Lopes FB, Everling DM, Minharro S, et al. (2015). Impacto da heterogeneidade de variância residual na avaliação genética de rebanho Nelore no Bioma Amazônia. Rev. Bras. Saúde Prod. Anim. 15: 1689-1699.

Gelfand AE and Smith AFM (1990). Sampling-based approaches to calculation marginal densities. J. Am. Stat. Assoc. 85: 398-409. https://doi.org/10.1080/01621459.1990.10476213

Henderson CR (1976). A Simple Method for Computing the Inverse of a Numerator Relationship Matrix Used in Prediction of Breeding Values. Biometrics 32: 69-83. https://doi.org/10.2307/2529339

Heydarpour M, Schaeffer LR and Yazdi MH (2008). Influence of population structure on estimates of direct and maternal parameters. J. Anim. Breed. Genet. 125: 89-99. https://doi.org/10.1111/j.1439-0388.2007.00703.x

Karacaören B, Jaffrézic F and Kadarmideen HN (2006). Genetic parameters for functional traits in dairy cattle from daily random regression models. J. Dairy Sci. 89: 791-798. https://doi.org/10.3168/jds.S0022-0302(06)72141-5

Laureano MMM, Bignardi AB, El Faro L, Cardoso VL, et al. (2014). Random regression models using different functions to model milk flow in dairy cows. Genet. Mol. Res. 13: 7528-7541. https://doi.org/10.4238/2014.September.12.20

Lopes FB, Magnabosco CU, Paulini F, da Silva MC, et al. (2013). Genetic analysis of growth traits in Polled Nellore cattle raised on pasture in tropical region using Bayesian approaches. PLoS One 8: e75423. https://doi.org/10.1371/journal.pone.0075423

Lopes JS, Rorato PRN, Weber T, et al. (2008). Efeito da interação genótipo x ambiente sobre o peso ao nascimento, aos 205 e aos 550 dias de idade de bovinos da raça Nelore na Região Sul do Brasil. Rev. Bras. Zootec. 37: 54-60. https:// doi.org/10.1590/S1516-35982008000100007

Malhado CHM, Carneiro PLS, Martins Filho R, et al (2005). Tendência e Parâmetros Genéticos para o Peso aos 205 Dias de Idade em Bovinos da Raça Nelore Mocho no Estado da Bahia.

Malhado CHM, Malhado ACM, Ramos AA, Carneiro PLA, et al. (2012). Genetic parameters by Bayesian inference for dual purpose Jaffarabadi buffaloes. 55: 567-576.

Meyer K (1997). Estimates of genetic parameters for weaning weight of beef cattle accounting for direct-maternal environmental covariances. Livest. Prod. Sci. 52: 187-199. https://doi.org/10.1016/S0301-6226(97)00144-9

Misztal I, Tsuruta S, Lourenco D, Aguilar I, et al. (2015). Manual for BLUPF90 familyof programs. Available at [http:// nce.ads.uga.edu/wiki/lib/exe/fetch.php?media=blupf90_all1.pdf]. Accessed October 24, 2015.

Mrode R and Coffey M (2008). Understanding cow evaluations in univariate and multivariate animal and random regression models. J. Dairy Sci. 91: 794-801. https://doi.org/10.3168/jds.2007-0506

Robinson DL (1996). Models which might explain correlations between directand maternal genetic effects. Livest. Prod. Sci. 45: 111-122. https://doi.org/10.1016/0301-6226(96)00002-4

SAS (2004) Institute Inc. Statistical Analysis System user’s guide. Version 9.2 ed. Cary: SAS Institute, USA.

Tosh JJ and Kemp RA (1994). Estimation of variance components for lamb weights in three sheep populations. J. Anim. Sci. 72: 1184-1190.

Silva JAV, Dias LT and Albuquerque LG (2005). Estudo genético da precocidade sexual de novilhas em um rebanho Nelore. Rev. Bras. Zootec. 34: 1568-1572. https://doi.org/10.1590/S1516-35982005000500017

Van Kaam JBCHM (1997). GIBANAL - Analyzing program for Markov Chain Monte Carlo sequences. Version 2.4, Netherlands.

VanRaden PM, Tooker ME, Wright JR, Sun C, et al. (2014). Comparison of single-trait to multi-trait national evaluations for yield, health, and fertility. J. Dairy Sci. 97: 7952-7962. https://doi.org/10.3168/jds.2014-8489

Vergara OD, Ceron-Muñoz MF, Arboleda EM, Orozco Y, et al. (2009). Direct genetic, maternal genetic, and heterozygosity effects on weaning weight in a Colombian multibreed beef cattle population. J. Anim. Sci. 87: 516-521. https://doi. org/10.2527/jas.2007-0636

Willham RL (1972). The role of maternal effects in animal breeding: III. Biometrical aspects of maternal effects in animals. J. Anim. Breed Genet. 35: 1288-1293.

Yokoo MJI, Albuquerque LG, Lôbo RB, Sainz RB, et al. (2007). Estimativas de parâmetros genéticos para altura do posterior, peso e circunferência escrotal em bovinos da raça Nelore. Rev. Bras. Zootec. 36: 1761-1768. https://doi. org $/ 10.1590 / \mathrm{S} 1516-35982007000800008$

Genetics and Molecular Research 16 (3): gmr16039606 